\title{
NEW RECORDS OF THE RARE METALLOPHILIC LICHEN PORPIDIA MELINODES FROM HORNFELS IN THE SUDETY MTS
}

\author{
MARIA KossowsKa
}

Maria Kossowska, Laboratory of Lichenology, Department of Botany, Institute of Environmental Biology, University of Wroctaw, Kanonia 6/8, 50-328 Wroclaw, Poland; e-mail: maria.kossowska@uni.wroc.pl

Porpidia melinodes (Körb.) Gowan \& Ahti is a saxicolous lichen species described in 1993 as a vegetatively reproducing counterpart of $P$. flavicunda (Ach.) Gowan (Gowan \& Ahti 1993). Both these species belong to the Porpidia speirea group, characterized by having thin excipular hyphae, no sharp contrast between the margin and medulla of the excipulum, and having the confluentic chemosyndrome as the primary chemotype (Buschbom \& Mueller 2004; Fryday 2005). Within this group, $P$. flavicunda and $P$. melinodes form a separate subgroup of taxa having an obligate orange thallus and a nonamyloid medulla (Fryday 2005).

Porpidia melinodes is one of the rarest elements of the lichen biota of Poland. Previously the only confirmed locality of this species was on a slope of Śnieżka Mt. in the Karkonosze/ Krkonoše Mts (Jabłońska 2009, 2012), where it grew on mineral-rich hornfels. It was also reported from five localities on noncalcareous sandstone in Pilsko and on the Babia Góra massif (Carpathians; Nowak 1998). However, Jabłońska (2009, 2012) excluded these localities as unverified in her study of the genus Porpidia Körb. in Poland, because the corresponding herbarium material was not available.

In 2013, during field work in the zone of hornfels rock in the Góry Izerskie Mts, which are adjacent to the Karkonosze/Krkonoše Mts, I found a new abundant population of this species. The lichens grew there on insolated metamorphic rocks rich in minerals (hornfels) at ca 1040-1060 m a.s.l., in association with common lichen species typical for siliceous rock, including Acarospora fuscata (Nyl.) Th. Fr., Candelariella coralliza (Nyl.) H. Magn., Lecanora intricata (Ach.) Ach., L. polytropa (Ehrh. ex Hoffm.) Rabenh., Lecidea confluens (Weber) Ach., Protoparmelia badia (Hoffm.) Hafellner, Rhizocarpon geographicum (L.) DC., Umbilicaria polyphylla (L.) Baumg. and another metallophilic species, Lecidea silacea (Hoffm.) Ach. (locality at Wysoki Kamień Mt.). Thalli of Porpidia melinodes were recorded on both exposed horizontal surfaces and vertical surfaces in basal parts of rock complexes, as well as on smaller boulders and stones.

Porpidia melinodes is characterized by having a rather thin, orange or partially orange-gray thallus with an uneven upper surface and a welldeveloped, dull gray to black prothallus (Fig. 1).

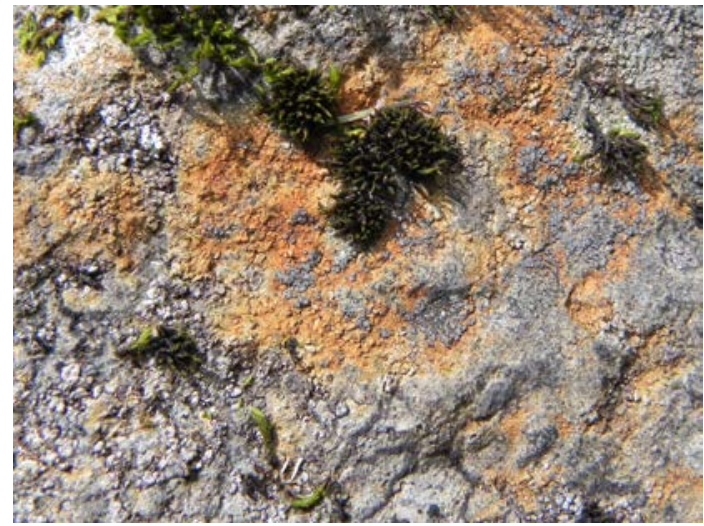

Fig. 1. Porpidia melinodes (Körb.) Gowan \& Ahti at the Wysoki Kamień Mt. locality, Góry Izerskie Mts. 
Apothecia are generally rare and were not observed in the examined material. The most characteristic trait of the species consists in numerous crater-like soralia delimited by a white rim, initially solitary and rounded, later grouped in larger aggregates. The soredia are granular and dull gray, becoming greenish white when eroded. The thallus and soralia do not react with the standard reagents $\mathrm{K}, \mathrm{C}, \mathrm{Pd}$ and $\mathrm{I}$. In the collected material, secondary metabolites including confluentic acid, 2'-O-metyloperlatolic acid (minor) and stictic acid (present in one sample) were detected by TLC.

Porpidia melinodes occurs mainly in arctic and boreal zones of Europe and North America, where it is widespread and common (Buschbom \& Mueller 2005), but more southern localities are also known. The species has been reported from Greenland (Hansen 1999), Iceland (Kristinsson \& Heidmarsson 2009), Svalbard (Elvebakk \& Hertel 1997), Norway, Sweden and Finland (Santesson et al. 2004), Great Britain and Ireland (Fryday 2005), Spain (Llimona \& Hladun 2001), Poland (Jabłońska 2009, 2012), the Czech Republic (Jabłońska et al. 2011) and Cyprus (Litterski \& Mayrhofer 1998).

Some authors consider $P$. melinodes to be a metallophilic species preferring metal-rich siliceous rocks (Purvis \& Halls 1995; Fryday et al. 2009). The hornfels zone in the Góry Izerskie Mts, and especially the Wysoki Kamień Mt. locality, has long been known as a place where metallophyte lichens occur. Among others, two obligate metallophilic species, Rhizocarpon oederi and Lecidea silacea, were reported from there (Körber 1855; Stein 1879). However, hornfels is not a typical metalliferous substrate with a high concentration of Fe ions, but only a type of rock which may be locally enriched in various minerals, among them iron compounds (Aleksandrowski et al. 2013). The other certain Polish record of $P$. melinodes also came from hornfels (see above), but at the closest locality in West Bohemia (Jabłońska et al. 2012) it grew on gneiss, and the five unconfirmed Carpathian records were from sandstone. Therefore the ecological spectrum of Porpidia melinodes seems to be wider and this lichen may possibly prefer mineral-enriched rather than strictly metalrich rock substrates.

SPECIMENS EXAMINED. [Ea-78 ATPOL grid square]: POLAND. GóRY IZERSKIE MTs (Wysoki Grzbiet ridge): Zwalisko Mt., Wieczorny Zamek rocks, on hornfels, 19 July 2013, M. Kossowska (hb. Kossowska 1333); Wysoki Kamień Mt., rocks at summit, on hornfels, 18 July 2013, M. Kossowska (hb. Kossowska 1335).

ACKNOWLedGements. I warmly thank Dr. Katarzyna Szczepańska (Wrocław) for identifying secondary metabolites by thin-layer chromatography, and the anonymous reviewer for helpful remarks on the manuscript.

\section{REFERENCES}

Aleksandrowski P., SŁaby E., Szuszkiewicz A., GalbarCZYK-GĄSIOROWSKa L., MADEJ S. \& SZEląG E. 2013. Budowa geologiczna. In: R.KNAPIK \& A. RAJ (eds), Przyroda Karkonoskiego Parku Narodowego. pp. 7-46. Karkonoski Park Narodowy, Jelenia Góra.

Buschвom J. \& Mueller G. M. 2004. Resolving evolutionary relationships in the lichen-forming genus Porpidia and related allies (Porpidiaceae, Ascomycota). Molec. Phylogen. Evol. 32: 66-82.

Buschвom J. \& Mueller G. M. 2005. Testing „species pair“ hypotheses: evolutionary processes in the lichen-forming species complex Porpidia flavocerulescens and Porpidia melinodes. Molec. Biol. Evol. 23(3): 574-586.

Elvebakk A. \& Hertel H. 1997. A catalogue of Svalbard lichens. In: A. Elvebakk \& P. Prestrud (eds), A catalogue of Svalbard plants, fungi, algae, and cyanobacteria. Norsk Polarinstitutts Skrifter 198: 271-359.

Fryday A. M. 2005. The genus Porpidia in northern and western Europe, with special emphasis on collections from the British Isles. Lichenologist 37: 1-35.

Fryday A. M., Gilbert O. L., Galloway D. J. \& Coppins B. J. 2009. Porpidia Körb. (1855). In: C. W. Sмith, A. Aptroot, B. J. Coppins, F. A. Letcher, O. L. Gilbert, P. W. JAMES \& P. A. Wolseley (eds), The lichens of Great Britain and Ireland, pp. 739-749. The British Lichen Society, London.

Gowan S. P. \& Ahti T. 1993. Status of the lichen genus Porpidia in eastern Fennoscandia. Ann. Bot. Fenn. 30: 53-75.

HANSEN E. S. 1999. Epilithic lichens on iron-and copper containing crusts at Qeqertarsuaq, Central West Greenland. Graphis Scripta 10: 7-12.

JABŁońSKa A. 2009. The lichen genus Porpidia in Poland. II. Species with soredia. Herzogia 22: 135-146.

JablońsKa A. 2012. The lichen genus Porpidia Körb. in Po- 
land. Monogr. Bot. 102: 5-123 (in Polish with English summary).

JABŁońSKa A., PALICE Z. \& KuKwa M. 2011. Notes in sorediate Porpidia species with a rusty coloured thallus from the Czech Republic. Bryonora 47: 8-13.

KöRBER G. 1855. Systema lichenum Germaniae. Die Flechten Deutschlands (insbesondere Schlesiens). Verlag Trevendt \& Granier, Breslau.

Kristinsson H. \& Heidmarsson S. 2009. Checklist of lichens in Iceland. [February 2004]. http://www.floraislands.is/ fletlist-2009.htm.

Litterski B. \& Mayrhofer H. 1998. Catalogue of lichenized and lichenicolous fungi of Cyprus. Stud. Geobot. 16: $57-70$.

Llimona X. \& Hladun N. L. 2001. Checklist of the lichens and lichenicolous fungi of the Iberian Peninsula and Balearic Islands. Bocconea 14: 1-581.

NowaK J. 1998. The lichens (lichenized fungi) occurrence in the Beskid Wyspowy, Beskid Żywiecki and Pasmo Jałowca ranges, and the Babia Góra massif. Monogr. Bot. 83: 1-131 (in Polish with English summary).

Purvis O. W. \& Halls C. 1995. A review of lichens in metalenriched environments. Lichenologist 28(6): 571-601.

Santesson R., Moberg R., Nordin A., Tønsberg T. \& VitiKAINEN O. 2004. Lichen-forming and lichenicolous fungi of Fennoscandia. Museum of Evolution, Upsala University, Uppsala.

SteIN B. 1879. Flechten. In: F. CoHn (ed.), Kryptogamenflora von Schlesien. Jahresb. Schles. Ges. Vaterl. Kultur 2(2): 1-400.

Received 23 July 2014 